\title{
Methylation of leukocyte DNA and ovarian cancer: relationships with disease status and outcome
}

\author{
Brooke L Fridley ${ }^{1 *}$, Sebastian M Armasu², Mine S Cicek², Melissa C Larson², Chen Wang ${ }^{2}$, Stacey J Winham², \\ Kimberly R Kalli ${ }^{3}$, Devin C Koestler ${ }^{1,4}$, David N Rider ${ }^{2}$, Viji Shridhar ${ }^{5}$, Janet E Olson², Julie M Cunningham ${ }^{5}$ \\ and Ellen L Goode ${ }^{2}$
}

\begin{abstract}
Background: Genome-wide interrogation of DNA methylation (DNAm) in blood-derived leukocytes has become feasible with the advent of CpG genotyping arrays. In epithelial ovarian cancer (EOC), one report found substantial DNAm differences between cases and controls; however, many of these disease-associated CpGs were attributed to differences in white blood cell type distributions.

Methods: We examined blood-based DNAm in 336 EOC cases and 398 controls; we included only high-quality CpG loci that did not show evidence of association with white blood cell type distributions to evaluate association with case status and overall survival.

Results: Of 13,816 CpGs, no significant associations were observed with survival, although eight CpGs associated with survival at $p<10^{-3}$, including methylation within a $C p G$ island located in the promoter region of GABRE $(p=$ $\left.5.38 \times 10^{-5}, \mathrm{HR}=0.95\right)$. In contrast, $53 \mathrm{CpG}$ methylation sites were significantly associated with EOC risk $\left(\mathrm{p}<5 \times 10^{-6}\right)$. The top association was observed for the methylation probe cg04834572 located approximately $315 \mathrm{~kb}$ upstream of DUSP13 $\left(p=1.6 \times 10^{-14}\right)$. Other disease-associated CpGs included those near or within HHIP (cg14580567; $\left.p=5.6 \times 10^{-11}\right), \operatorname{HDAC3}\left(\operatorname{cg} 10414058 ; p=6.3 \times 10^{-12}\right)$, and SCR $\left(\operatorname{cg} 05498681 ; p=4.8 \times 10^{-7}\right)$.

Conclusions: We have identified several CpGs in leukocytes that are differentially methylated by case-control status. Since a retrospective study design was used, we cannot differentiate whether DNAm was etiologic or resulting from EOC; thus, prospective studies of EOC-associated loci are the critical next step.
\end{abstract}

Keywords: DNA methylation, CpG genotyping arrays, Epithelial ovarian cancer, Pathway, Etiology, Overall survival

\section{Background}

The role of DNA methylation (DNAm) in ovarian cancer is multi-faceted. While tumor tissue shows clear methylation patterns associating with histopathology, the role of blood-based DNAm patterns on disease etiology and outcome has been a subject of growing interest [1-4]. This includes study of variation in inherent global methylation levels, the relationship between exogenous exposures and leukocyte methylation, and the role of inherited variants on leukocyte methylation (mQTL) [5-8]. Five of the eleven

\footnotetext{
* Correspondence: bfridley@kumc.edu

'Department of Biostatistics, University of Kansas, Medical Center, 3901

Rainbow Blvd, Kansas City, KS 66160, USA

Full list of author information is available at the end of the article
}

confirmed ovarian cancer susceptibility variants and an endometriosis locus are located in homeobox gene clusters $(H O X A, H O X B$, and $H O X D)$, homeobox related genes $(H N F 1 B)$, or genes expressed in early progenitor cells (TERT) [9-13]. Thus, we hypothesize that DNAm levels in circulating systemic leukocytes of ovarian cancer cases and controls may differ, and that among cases, leukocyte methylation may vary by disease outcome.

Previous work by Teschendorff et al. (2009) [14] identified peripheral blood methylation signatures that predicted ovarian cancer case-control status using methylation measurements at more than 27,000 CpGs in 113 cases and 148 controls. However, as pointed out in the discussion by Teschendorff et al. and subsequently by Koestler et al. 
(2009) [15] and Houseman et al. (2012) [16], blood-based methylation measurements are dependent on distribution of white blood cell (leukocyte) types and the distribution of cell types is also related to disease status (i.e., confounding). Therefore, in order to minimize confounding by distribution of cell types, we performed case-control and survival analyses using 336 EOC cases and 398 controls, accounting for cell type associations to better understand the role of blood-based DNAm in ovarian cancer risk and survival.

\section{Methods}

\section{Study participants}

Eligible EOC cases were women aged 20 years or above who were ascertained between 2000 and 2009 at the Mayo Clinic within one year of diagnosis with pathologically confirmed primary epithelial ovarian, fallopian tube, or primary peritoneal cancer. Controls were recruited from among women seen at the Mayo Clinic for general medical examinations and individually-matched to cases on age (1-year) and area of residence. Women were of European descent and residing in a six-state area surrounding Minnesota, representing $>85 \%$ of EOC cases seen at the Mayo Clinic, and cases had not begun chemotherapeutic treatment prior to blood draw. Table 1 summarizes characteristics of 734 participants, following quality control as outlined below. Peripheral blood (leukocytes) was used as the source of DNA, which was extracted from 10 to $15 \mathrm{~mL}$ of fresh peripheral blood by the Gentra AutoPure LSPuregene salting out methodology (Gentra) and stored at $-80^{\circ} \mathrm{C}$. Samples were bar-coded to ensure accurate processing. This work was approved by the Mayo Clinic Institutional Review Boards and all participants provided written informed consent.

\section{DNA methylation assays and arrays}

Peripheral blood (leukocytes) was used as the source of DNA. DNA was extracted from four milliliters of fresh peripheral blood using the Autogen Flexstar instrument utilizing Flexigene chemistry (salting out methodology). Blood is aliquoted for DNA extraction using an automated liquid handler with barcoding to ensure proper sample placement. Post-DNA extraction, DNA is aliquoted into a permanent storage tube utilizing an automated liquid handler with barcoding, again, to ensure proper sample placement. DNA samples are assessed for quality and concentration using a Trinean DropSense 96 spectrophotometer and DNA is then stored longterm at $-80^{\circ} \mathrm{C}$. The leukocyte-derived DNA (1 ug) was bisulfite modified (BSM) using the Zymo EZ96 DNA Methylation Kit (Zymo Research, Orange, CA) according to the manufacturer's protocol. BSM DNA (250 ng) was then assayed on 96 well plates in three batches at the Mayo Clinic Molecular Genome Facility (Rochester, MN): Batch 1 used the
Infinium HumanMethylation27 BeadChip on 84 cases and 91 controls, Batch 2 used this array on 172 cases and 176 controls and Batch 3 used Illumina Infinium HumanMethylation450 BeadChip on 156 cases and 157 controls. Methylation status at the target CpG sites was determined by comparing the ratio of fluorescent signal from the methylated allele to the sum from the fluorescent signal from both methylated and unmethylated alleles (i.e., the beta value).

To assess the quality of the DNAm data produced from the Illumina arrays, Centre d'Etudes du Polymorphisme Humain (CEPH) DNA, positive BSM controls (placental DNA) and negative BSM controls (whole genome amplified [WGA] DNA) were assayed within each batch. For the HumanMethylation27 BeadChips (Batch 1 and Batch 2), 9 CEPH DNA, 12 positive control DNA samples and 8 negative control DNA samples were also assayed, in addition to 12 replicate/duplicate samples. Similarly, for the HumanMethylation450 BeadChip batch (Batch 3), 6 CEPH samples, 11 positive control samples, 6 negative control samples and 6 replicate samples were assayed. Lastly, twenty duplicate samples were assayed using both Illumina Infinium HumanMethylation27 and HumanMethylation450 BeadChip in order to compare the methylation levels between the two arrays.

\section{Quality control and normalization}

Using Illumina GenomeStudio software, DNAm values from the HumanMethylation27 BeadChip assays were scored as beta values, ranging from 0 (unmethylated) to 1 (methylated), resulting in methylation beta values for 27,578 probes. Quality control was done for Batch 1 and Batch 2 combined and then separately for Batch 3 . Probes were then excluded if they were on the $\mathrm{Y}$ chromosome, positioned at a single nucleotide polymorphism (dbSNP build 137), had high beta values in BSM negative controls (beyond four standard deviations of mean), or were detected in less than $70 \%$ of samples. Quality control was also conducted at the sample level, based on the bisulfite conversion ratio and call rate rates (based on a detection p-value of 0.05). Histograms and scatterplots of these statistics were used to determine which samples to exclude (i.e., "outliers"). Similar quality control steps were completed for the samples assayed using the HumanMethylation450 BeadChips, which contained 485,577 CpG site-specific probes.

For the HumanMethylation27 BeadChip arrays, 25,922 (94\%) methylation probes passed quality control; for the HumanMethylation450, 441,716 (91\%) methylation probes passed quality control. The pairwise correlations for beta values among CEPH replicates were excellent $(\geq 0.97$ for Batches 1 and 2, and $>0.99$ for Batch 3), as were the intraclass correlations of beta values among $\mathrm{CEPH}$ replicates ( $>0.98$ for Batches 1 and 2, and $>0.99$ for Batch 3 ) and 
Table 1 Characteristics of study participants

\begin{tabular}{|c|c|c|c|c|}
\hline Variable & Batch 1* & Batch 2* & Batch $3^{\wedge}$ & Total \\
\hline \multicolumn{5}{|l|}{$\begin{array}{l}\text { Age at case } \\
\text { diagnosis }\end{array}$} \\
\hline N & 69 & 146 & 121 & 336 \\
\hline Mean (SD) & $60.2(12.0)$ & $63.3(12.8)$ & $62.2(11.3)$ & $62.3(12.1)$ \\
\hline Range & (33.0-82.0) & $(28.0-91.0)$ & $(33.0-86.0)$ & (28.0-91.0) \\
\hline \multicolumn{5}{|c|}{$\begin{array}{l}\text { Age at control } \\
\text { enrollment }\end{array}$} \\
\hline N & 87 & 176 & 135 & 398 \\
\hline Mean (SD) & $60.2(12.1)$ & $62.9(12.7)$ & $62.4(11.4)$ & $62.2(12.2)$ \\
\hline Range & $(33.0-85.0)$ & $(27.0-89.0)$ & $(33.0-88.0)$ & $(27.0-89.0)$ \\
\hline \multicolumn{5}{|l|}{$\begin{array}{l}\text { EOC case } \\
\text { vital status }\end{array}$} \\
\hline Alive & 35 (51\%) & $51(35 \%)$ & $59(49 \%)$ & 145 (43\%) \\
\hline Deceased & 34 (49\%) & 95 (65\%) & $62(51 \%)$ & 191 (57\%) \\
\hline \multicolumn{5}{|c|}{$\begin{array}{l}\text { Follow-up time } \\
\text { (years) }\end{array}$} \\
\hline Mean (SD) & $2.8(1.5)$ & $4.1(2.8)$ & $3.0(2.5)$ & $3.4(2.5)$ \\
\hline Range & $(0.1-6.4)$ & $(0.0-11.0)$ & $(0.1-11.4)$ & $(0.0-11.4)$ \\
\hline \multicolumn{5}{|l|}{ Parity } \\
\hline Nulliparous & $25(16 \%)$ & 47 (15\%) & $34(13 \%)$ & 106 (14\%) \\
\hline $1-2$ & 49 (32\%) & 104 (32\%) & 109 (43\%) & $262(36 \%)$ \\
\hline $3+$ & 77 (50\%) & $156(48 \%)$ & 97 (38\%) & 331 (45\%) \\
\hline Unknown & $4(2 \%)$ & $15(5 \%)$ & $16(6 \%)$ & $35(5 \%)$ \\
\hline \multicolumn{5}{|c|}{ Smoking status } \\
\hline Never/former & 140 (90\%) & $284(88 \%)$ & $213(83 \%)$ & 637 (87\%) \\
\hline Current & $10(6 \%)$ & $19(6 \%)$ & $20(8 \%)$ & $49(7 \%)$ \\
\hline Unknown & $6(4 \%)$ & 19 (6\%) & $23(9 \%)$ & $48(7 \%)$ \\
\hline \multicolumn{5}{|l|}{ Alcohol use } \\
\hline Current & $93(60 \%)$ & 172 (53\%) & $133(52 \%)$ & 398 (54\%) \\
\hline Former & $22(14 \%)$ & $50(16 \%)$ & 47 (18\%) & 119 (16\%) \\
\hline Never & $34(22 \%)$ & 73 (23\%) & 48 (19\%) & 155 (21\%) \\
\hline Unknown & $7(5 \%)$ & $27(8 \%)$ & $28(11 \%)$ & $62(8 \%)$ \\
\hline \multicolumn{5}{|l|}{$\begin{array}{l}\text { Histology, } \\
\text { cases only }\end{array}$} \\
\hline Serous & $46(66.7 \%)$ & 97 (66.4\%) & $100(82.6 \%)$ & $243(72 \%)$ \\
\hline Endometrioid & $16(23.2 \%)$ & $32(22 \%)$ & 15 (12\%) & $63(19 \%)$ \\
\hline Clear cell & $4(5.8 \%)$ & $9(6 \%)$ & $3(3 \%)$ & $16(5 \%)$ \\
\hline Mucinous & $1(1.4 \%)$ & $4(3 \%)$ & $3(3 \%)$ & $8(2 \%)$ \\
\hline Other & $2(2.9 \%)$ & $4(3 \%)$ & $0(0 \%)$ & $6(2 \%)$ \\
\hline \multicolumn{5}{|c|}{ Grade, cases only } \\
\hline Grade 1 or 2 & $11(16 \%)$ & $29(20 \%)$ & $16(13 \%)$ & $56(17 \%)$ \\
\hline Grade 3 or 4 & $56(81 \%)$ & $117(80 \%)$ & $103(85 \%)$ & $276(82 \%)$ \\
\hline Unknown & $2(3 \%)$ & $0(0 \%)$ & $2(2 \%)$ & $4(1 \%)$ \\
\hline \multicolumn{5}{|c|}{ Stage, cases only } \\
\hline Stage | or || & $14(20 \%)$ & $39(27 \%)$ & $21(17 \%)$ & $74(22 \%)$ \\
\hline Stage III or IV & 55 (80\%) & 107 (73\%) & 100 (83\%) & 262 (78\%) \\
\hline
\end{tabular}

Table 1 Characteristics of study participants (Continued)

\begin{tabular}{lcccc}
\hline $\begin{array}{l}\text { Surgical debulking, } \\
\text { cases only }\end{array}$ & & & & \\
Optimal $(<1 \mathrm{~cm})$ & $57(83 \%)$ & $123(84 \%)$ & $105(87 \%)$ & $285(85 \%)$ \\
Sub-optimal $(>1 \mathrm{~cm})$ & $11(16 \%)$ & $22(15 \%)$ & $14(12 \%)$ & $47(14 \%)$ \\
Unknown & $1(1 \%)$ & $1(1 \%)$ & $2(2 \%)$ & $4(1 \%)$ \\
Ascites, cases only & & & & \\
No & $39(57 \%)$ & $65(45 \%)$ & $76(63 \%)$ & $180(54 \%)$ \\
Yes & $23(33 \%)$ & $42(29 \%)$ & $32(26 \%)$ & $97(29 \%)$ \\
Unknown & $7(10 \%)$ & $39(27 \%)$ & $13(11 \%)$ & $59(18 \%)$ \\
\hline
\end{tabular}

*Assayed using the Illumina Infinium HumanMethylation27 BeadChip.

$\wedge$ Assayed using the Illumina Infinium HumanMethylation450 BeadChip.

among duplicated study participant samples $(>0.93$ for Batches 1 and 2, and $>0.81$ for Batch 3). For 20 samples assessed across batches, the intra-class correlation for beta values of the 24,520 overlapping probes in the HumanMethylation27 and HumanMethylation450 BeadChips was $>0.88$. Of samples in Batches 1 and 2, 6 were excluded based on call rates, and one failed bisulfite conversion; in Batch 3, 10 samples were removed following quality control ( 9 samples failed the bisulfite conversion, one sample with low mean methylation beta value across probes). Following exclusions, we included 69 cases and 87 controls in Batch 1, 146 cases and 176 controls in Batch 2, and 121 cases and 135 controls in Batch 3.

We assessed possible differences by plate and chips within plates (8 BeadChips per plate were assessed with 12 DNAs each) through principal component analyses. Based on the assessment of technical artifacts using principal component analyses, a plate effect was observed within each of the three batches and a chip within batch effect for the HumanMethylation27 data (Additional file 1: Figure S1). Therefore, we adjusted for a plate effect for batch 3 and for chip within plate effect for batches 1 and 2 using a linear model of the logit-transformed beta value for each CPG site, with the unstandardized residuals saved. The logit-transformed locus mean was added back onto the residuals followed by the transformation of the residual to the 0 to 1 scale, producing an "adjusted beta" value for all $\mathrm{CpG}$ sites.

Finally, we restricted analyses to probes in common between the DNAm arrays following quality control, excluding 9,341 CpG probes on the Illumina Infinium HumanMethylation27 shown to associate with cell type distribution at q-value $<0.05[15,16]$, as well as 1,363 CpG probes found by Chen et al. to be non-specific (i.e., mapped to multiple places along the genome) [17]. Thus, analyses focused on the remaining 13,816 CpG probes (i.e., 24,520 probes in common between the two panels following quality control minus 9,341 probes associated with cell type distribution minus 1,363 non-specific probes). 


\section{Statistical association analysis}

We analyzed each batch separately using Van der Waerden rank, or rank-based inverse Gaussian, transformed beta values and combined results across batch using meta-analysis techniques. This allowed us to examine similarity of effects across batches and to estimate the combined effect. Meta-analysis was completed using a random effect meta-analysis. A Woolf's test of homogeneity of regression coefficients across batches was performed, i.e. the distribution of regression estimates across batches for each probe is compatible with that expected given a common regression estimate. All statistical tests were 2-sided, and analyses of individual batches were carried out using SAS (version 9.3; SAS Institute Inc., Cary, NC) and R (version 2.14.0). Meta-analyses were carried out using the $R$ package rmeta (http://CRAN.R-project.org/package $=r-$ meta). To control for multiple testing, associations with $\mathrm{p}<5 \times 10^{-6}$ were considered statistically significant (e.g., Bonferroni adjustment based on number of independent tests). Pathway analysis used Ingenuity Pathway Analysis (IPA) (Ingenuity Systems, www.ingenuity. com) for genes closest to $\mathrm{CpG}$ probes associated with disease status or outcome at $\mathrm{p}<0.0001$.

The following linear model was used to determine if DNAm levels differ between EOC cases and matched controls for each CpG site. Let, $Y_{i j}=\alpha_{j}+\beta_{j} X_{i}+\gamma_{j}^{T} Z_{i}+e_{i j}$, where $Y_{i j}$ represents the adjusted methylation beta value for subject $i$ and CpG probe $j(j=1 \ldots, 13816), X_{i}$ represents disease status for subject $i$ ( 1 if case and 0 if control), $Z_{i}$ represents covariates for subject $i$ and $\epsilon_{i j} \sim N\left(0, \sigma_{j}^{2}\right)$. To identify covariates that differ between EOC cases and controls to include in the model (i.e., potential confounders), potential covariates were examined for association with disease status within a stepwise logistic regression model, resulting in the inclusion of parity/age at first live birth combination (nulliparous, 1-2 and age $<=20$ years, 1-2 and age $>20$ years, $3+$ and age $<=20$ years, $3+$ and age $>=20$ years, missing), current alcohol use (never, former, current, missing), current smoking status (never or former, current, missing), enrollment year, and recruitment state (MN vs. non-MN). For each CpG probe $j$, the disease status parameter $\left(\hat{\beta}_{j}\right)$ was estimated using the rank-transformed adjusted beta methylation values, along with a 95\% confidence interval (CI).

We assessed associations of methylation beta values with overall survival (OS) using Cox proportional hazards regression analyses, adjusted for age at diagnosis, tumor stage (III/IV, I/ II), presence of ascites (yes, no, missing) and volume of residual tumor following debulking surgery ( $<1 \mathrm{~cm},>1 \mathrm{~cm}$, missing) based on stepwise Cox regression analysis. The proportionality assumption was assessed by the analysis of scaled Schoenfeld residuals for all covariates included in the statistical analysis and found to be upheld [18]. We accounted for left truncation using start-stop counting process style of input and estimated hazards ratios (HR) and 95\% CIs [19].

\section{Results}

\section{Disease status and DNA methylation}

In a meta-analysis across the three batches (two sets of experiments involving the Illumina Infinium HumanMethylation27 beadchip and one experiment involving the Illumina Infinium HumanMethylation450 beadchip) evaluating association between each of the 13,816 CpG probes and ovarian cancer case-control status (336 cases, 398 controls), 30 CpGs showed p-value $\leq 5 \times 10^{-7}$ (Table 2), where none of the tests for heterogeneity of effects across batches were significant $(p>0.05)$. We confirmed that these $30 \mathrm{CpGs}$ were also included in the Koestler et al. (2012) analysis, and thus determined not to be associated with cell type distribution. Of these CpGs, the following were also replicated in an independent study $(\mathrm{p}<0.001)$ conducted by Teshendorff et al. [14]: cg04834572 near DUSP13, cg10414058 near HDAC3, cg19280776 near PAG1, and cg24959428 near GBP6. In addition to the replication of specific CpG sites, C19orf18 and MARCH1 contained CpG sites found to be replicated for association with EOC risk [20]. All CpG sites, with the exception of a CpG near PAG1, had negative parameter estimates indicating lower methylation in the cases as compared to controls (e.g., cases were hypo-methylated). Plots of the entire set of results for the 13,816 CpG sites (i.e., sites contained in both the $27 \mathrm{~K}$ and $450 \mathrm{~K}$ arrays, specific and not associated with cell type distribution) are presented in Figure 1A. The top association between methylation and disease status, which as also replicated, was observed for the CpG probe cg04834572 located approximately $315 \mathrm{~kb}$ upstream of DUSP13 on chromosome 10 (Figure 2A) with a meta-analysis p-value of $1.6 \times 10^{-14}$ and individual batch $\mathrm{p}$ values ranging from $2.1 \times 10^{-4}$ to $1.1 \times 10^{-6}$. DUSP13 is a member of the protein-tyrosine phosphatase superfamily and interacts with protein kinases involved in the regulation of cell proliferation and differentiation. Other significantly associated CpG sites were near biologically interesting/ relevant genes, such as SRC (cg05498681; $\left.\mathrm{p}=4.8 \times 10^{-7}\right)$

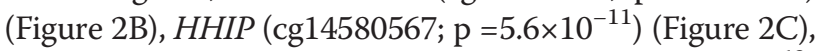
and replicated CpG near HDAC3 (cg10414058; $\left.\mathrm{p}=6.3 \times 10^{-12}\right)$ (Figure 2D).

To identify any commonality of highlighted genes within biological pathways, pathway analysis using Ingenuity Pathway Analysis (IPA) was completed for the 155 genes closest to the CpG probes (based on Illumina provided annotation) that were associated with disease status based on a liberal threshold of $p<0.0001$. The top pathways enriched for these 155 genes were the telomerase signaling (five genes in our top 155 were in the list of 99 genes within the telomerase signaling pathway; $\mathrm{p}=$ 
Table 2 CpG sites associated with disease status $\left(p \leq 5 \times 10^{-7}\right)$

\begin{tabular}{|c|c|c|c|c|c|c|c|c|c|c|c|c|c|}
\hline \multirow{2}{*}{ Probe ID } & \multirow{2}{*}{$\mathrm{Ch}$} & \multirow{2}{*}{$\begin{array}{l}\text { Position } \\
\text { (bp) }\end{array}$} & \multirow{2}{*}{$\begin{array}{l}\text { Nearest } \\
\text { genes }\end{array}$} & \multirow{2}{*}{$\begin{array}{l}\text { Location of nearest } \\
\text { gene (bp) }{ }^{\#}\end{array}$} & \multirow{2}{*}{$\begin{array}{l}\text { Location } \\
\text { to Island^ }\end{array}$} & \multicolumn{2}{|c|}{ Meta-Analysis $^{\S}$} & \multicolumn{2}{|c|}{ Batch 1} & \multicolumn{2}{|c|}{ Batch 2} & \multicolumn{2}{|c|}{ Batch 3} \\
\hline & & & & & & $\hat{\beta}$ & $\mathbf{P}$ & $\hat{\beta}$ & $P$ & $\hat{\beta}$ & $P$ & $\hat{\beta}$ & $P$ \\
\hline $904834572^{*}$ & 10 & 76868766 & DUSP13 & $76854190-76868970$ & Shelf & -0.65 & $1.6 \mathrm{E}-14$ & -0.82 & $2.1 \mathrm{E}-4$ & -0.55 & $6.0 \mathrm{E}-6$ & -0.73 & $1.1 \mathrm{E}-6$ \\
\hline \multirow[t]{2}{*}{ cg11722531 } & 19 & & $P C 2$ & $1450148-1473243$ & Shore & -0.62 & $2.7 \mathrm{E}-13$ & -0.64 & $3.5 \mathrm{E}-3$ & -0.54 & $6.4 \mathrm{E}-6$ & -0.74 & $1.3 \mathrm{E}-6$ \\
\hline & & & $\mathrm{FH} 2$ & $141016517-$ & & & & & & & & & \\
\hline \multirow[t]{2}{*}{$\operatorname{cg} 10414058^{*}$} & \multirow[t]{2}{*}{5} & \multirow[t]{2}{*}{141017903} & \multirow{2}{*}{ HDAC3 } & 141020631 & \multirow[t]{2}{*}{ Shore } & \multirow[t]{2}{*}{-0.94} & \multirow[t]{2}{*}{$6.3 \mathrm{E}-12$} & \multirow[t]{2}{*}{-1.13} & \multirow[t]{2}{*}{$3.5 \mathrm{E}-8$} & \multirow[t]{2}{*}{-0.71} & \multirow[t]{2}{*}{ 7.1E-10 } & \multirow[t]{2}{*}{-1.05} & \multirow[t]{2}{*}{$9.0 \mathrm{E}-12$} \\
\hline & & & & $141000443-141016423$ & & & & & & & & & \\
\hline cg14580567 & 4 & 145567271 & HHIP & $145567148-145659881$ & Island & -0.56 & $5.6 \mathrm{E}-11$ & -0.49 & 0.024 & -0.55 & $3.8 \mathrm{E}-6$ & -0.61 & $9.3 \mathrm{E}-5$ \\
\hline cg08245789 & 22 & 40289538 & ENTHD1 & $40139049-40289794$ & & -0.56 & $3.6 \mathrm{E}-10$ & -0.66 & 4.0E-3 & -0.43 & $3.9 \mathrm{E}-4$ & -0.69 & $6.5 \mathrm{E}-6$ \\
\hline cg27623214 & 19 & 58485726 & C19orf18 ${ }^{\dagger}$ & 58469805-58485902 & & -0.52 & $1.3 \mathrm{E}-9$ & -0.66 & $2.9 \mathrm{E}-3$ & -0.52 & $1.4 \mathrm{E}-5$ & -0.45 & $3.4 \mathrm{E}-3$ \\
\hline cg23877385 & 15 & 59908652 & GCNT3 & $59903982-59912210$ & & -0.52 & $2.2 \mathrm{E}-9$ & -0.46 & 0.043 & -0.53 & $1.3 \mathrm{E}-5$ & -0.52 & $6.3 \mathrm{E}-$ \\
\hline & $x$ & & SPACA5 & $47863734-47869130$ & & & & & & & & & \\
\hline 0490 & $x$ & & ZNF182 & $47834250-47863394$ & & & & & & & & & \\
\hline$g 22336401$ & 9 & 140336227 & ENTPD8 & $140328816-140335901$ & Island & -0.50 & $5.3 \mathrm{E}-9$ & -0.27 & 0.24 & -0.51 & $2.5 \mathrm{E}-5$ & -0.60 & $9.1 \mathrm{E}-5$ \\
\hline cg20775254 & 2 & 95940705 & PROM2 & $95940201-95957056$ & & -0.53 & $6.1 \mathrm{E}-9$ & -0.58 & $5.3 \mathrm{E}-3$ & -0.41 & $8.2 \mathrm{E}-4$ & -0.69 & $5.6 \mathrm{E}-6$ \\
\hline $\operatorname{cg} 19280776^{*}$ & 8 & 82024586 & PAG1 & $81880045-82024303$ & & 0.49 & $1.0 \mathrm{E}-8$ & 0.60 & $6.2 \mathrm{E}-3$ & 0.52 & $1.4 \mathrm{E}-5$ & 0.38 & 0.013 \\
\hline cg07634191 & 8 & 27850178 & SCARA5 & 27727399-27850369 & & -0.48 & $1.8 \mathrm{E}-8$ & -0.50 & 0.025 & -0.39 & $1.2 \mathrm{E}-3$ & -0.61 & $4.5 \mathrm{E}-5$ \\
\hline cg21244955 & 22 & & PI4KA & $21061979-21213100$ & & -0.49 & $2.2 \mathrm{E}-8$ & -0.47 & 0.039 & -0.48 & $6.6 \mathrm{E}-5$ & -0.50 & $1.3 \mathrm{E}-3$ \\
\hline & 6 & & & $43005355-43021683$ & & & & & & & & & \\
\hline & 0 & & MRPL2 & $43021767-43027242$ & & & & & & & & & \\
\hline & & & KCTD4 & $45766988-45775175$ & & & & & & & & & \\
\hline $904+5020$ & 13 & & GTF2F2 & $45694631-45858240$ & & & & & & & & & \\
\hline cg26787239 & 5 & 132008525 & $1 / 4$ & $132009678-132018370$ & & -0.48 & $2.9 \mathrm{E}-8$ & -0.50 & 0.025 & -0.50 & $3.4 \mathrm{E}-5$ & -0.43 & $4.8 \mathrm{E}-3$ \\
\hline cg07259382 & 4 & 164536228 & $M A R C H 1^{+}$ & $164445450-165304407$ & & -0.48 & $3.0 \mathrm{E}-8$ & -0.58 & $8.5 \mathrm{E}-3$ & -0.43 & $3.1 \mathrm{E}-4$ & -0.50 & $1.2 \mathrm{E}-3$ \\
\hline $\operatorname{cg} 14808739$ & 17 & 17741098 & SREBF1 & $17714663-17740325$ & Shore & -0.48 & 3.7E-8 & -0.41 & 0.063 & -0.52 & $2.3 \mathrm{E}-5$ & -0.44 & $3.8 \mathrm{E}-3$ \\
\hline cg00065385 & 9 & 111623395 & ACTL7A & $111624603-111626035$ & & -0.47 & $6.1 \mathrm{E}-8$ & -0.50 & 0.026 & -0.49 & $5.0 \mathrm{E}-5$ & -0.43 & $6.9 \mathrm{E}-3$ \\
\hline cg04721883 & $x$ & 103499577 & $E S X_{1}$ & 103494719-103499599 & Island & -0.46 & $7.6 \mathrm{E}-8$ & -0.40 & 0.068 & -0.38 & 1.7E-3 & -0.62 & $4.6 \mathrm{E}-5$ \\
\hline cg21400640 & $x$ & 12992967 & TMSBAX & 12993226-12995346 & Shore & -0.46 & 1.1E-7 & -0.50 & 0.029 & -0.46 & $1.4 \mathrm{E}-4$ & -0.44 & 4.0E-3 \\
\hline cg11871280 & 12 & 60082038 & SLC16A7 & $59989821-60183636$ & & -0.45 & 1.7E-7 & -0.24 & 0.28 & -0.51 & $2.4 \mathrm{E}-5$ & -0.46 & $3.1 \mathrm{E}-3$ \\
\hline cg09261015 & $x$ & 103499647 & $E S X 1$ & 103494719-103499599 & Island & -0.45 & $2.1 \mathrm{E}-7$ & -0.46 & 0.046 & -0.39 & $1.1 \mathrm{E}-3$ & -0.54 & 4.7E- - \\
\hline cg18731813 & $x$ & 100805683 & $A R M C X 1$ & $100805514-100809683$ & Shelf & -0.44 & $2.4 \mathrm{E}-7$ & -0.23 & 0.30 & -0.46 & $1.3 \mathrm{E}-4$ & -0.51 & 7.3E-4 \\
\hline cg23279136 & $x$ & 74375966 & $A B C B 7$ & $74273105-74376132$ & & -0.44 & $3.2 \mathrm{E}-7$ & -0.62 & $6.3 \mathrm{E}-3$ & -0.33 & $5.7 \mathrm{E}-3$ & -0.54 & $4.9 \mathrm{E}-4$ \\
\hline cg02254461 & 3 & 39195904 & CSRNP1 & 39183342-39195102 & Shore & -0.44 & $3.6 \mathrm{E}-7$ & -0.37 & 0.10 & -0.48 & $9.1 \mathrm{E}-5$ & -0.42 & $6.1 \mathrm{E}-3$ \\
\hline $\operatorname{cg} 26246138$ & $x$ & 18372612 & SCML2 & $18257433-18372844$ & Island & -0.44 & $3.8 \mathrm{E}-7$ & -0.37 & 0.096 & -0.37 & $2.3 \mathrm{E}-3$ & -0.57 & $1.6 \mathrm{E}-4$ \\
\hline cg24959428* & 1 & 89829951 & GBP6 & 89829436-89853719 & & -0.44 & 4.1E-7 & -0.50 & 0.025 & -0.42 & $5.2 \mathrm{E}-4$ & -0.44 & 4.4E-3 \\
\hline cg05498681 & 20 & 35973318 & $S R C$ & $35973088-36033821$ & Shore & -0.44 & $4.8 \mathrm{E}-7$ & -0.17 & 0.45 & -0.53 & $1.3 \mathrm{E}-5$ & -0.41 & $8.1 \mathrm{E}-3$ \\
\hline cg01377911 & 19 & 49568036 & NTF4 & $49564397-49567124$ & & -0.43 & $5.0 \mathrm{E}-7$ & -0.38 & 0.086 & -0.37 & $2.3 \mathrm{E}-3$ & -0.55 & $2.5 \mathrm{E}-4$ \\
\hline
\end{tabular}

"Locations based on NCBI (www.ncbi.nlm.nih.gov), build 37.

$\wedge$ Shore $\mathrm{CpG}$ sites defined to be within $+/-2 \mathrm{~kb}$ from CpG island; Shelf CpG sites defined to be within $+/-2 \mathrm{~kb}$ of $\mathrm{CpG}$ Shore.

${ }^{5}$ All tests for heterogeneity of effects across the three batches were non-significant $(p>0.05)$; analysis adjusted for age at first live birth, alcohol use, smoking status, enrollment year, and recruitment state; a negative parameter estimate indicates lower methylation in the cases as compared to the control (e.g., cases where hypomethylated).

*Same CpG site found to be associated with EOC risk $(p \leq 0.001)$ in a prior report [14].

${ }^{+} \mathrm{CpG}$ sites near this gene found to be associated with EOC risk in a prior report [14].

$1.24 \times 10^{-3}$ for enrichment of pathway) and the paxillin signaling (five genes in our top 155 were in the list of 110 genes within the paxillin signaling pathway; $\mathrm{p}=$ $\left.1.42 \times 10^{-3}\right)$. The five genes in the telomerase signaling pathway with methylation associated with disease status at $\mathrm{p}<0.0001$ were HDAC3 $\left(\mathrm{p}=6.33 \times 10^{-12}\right), I L 2 R G(\mathrm{p}=$ 


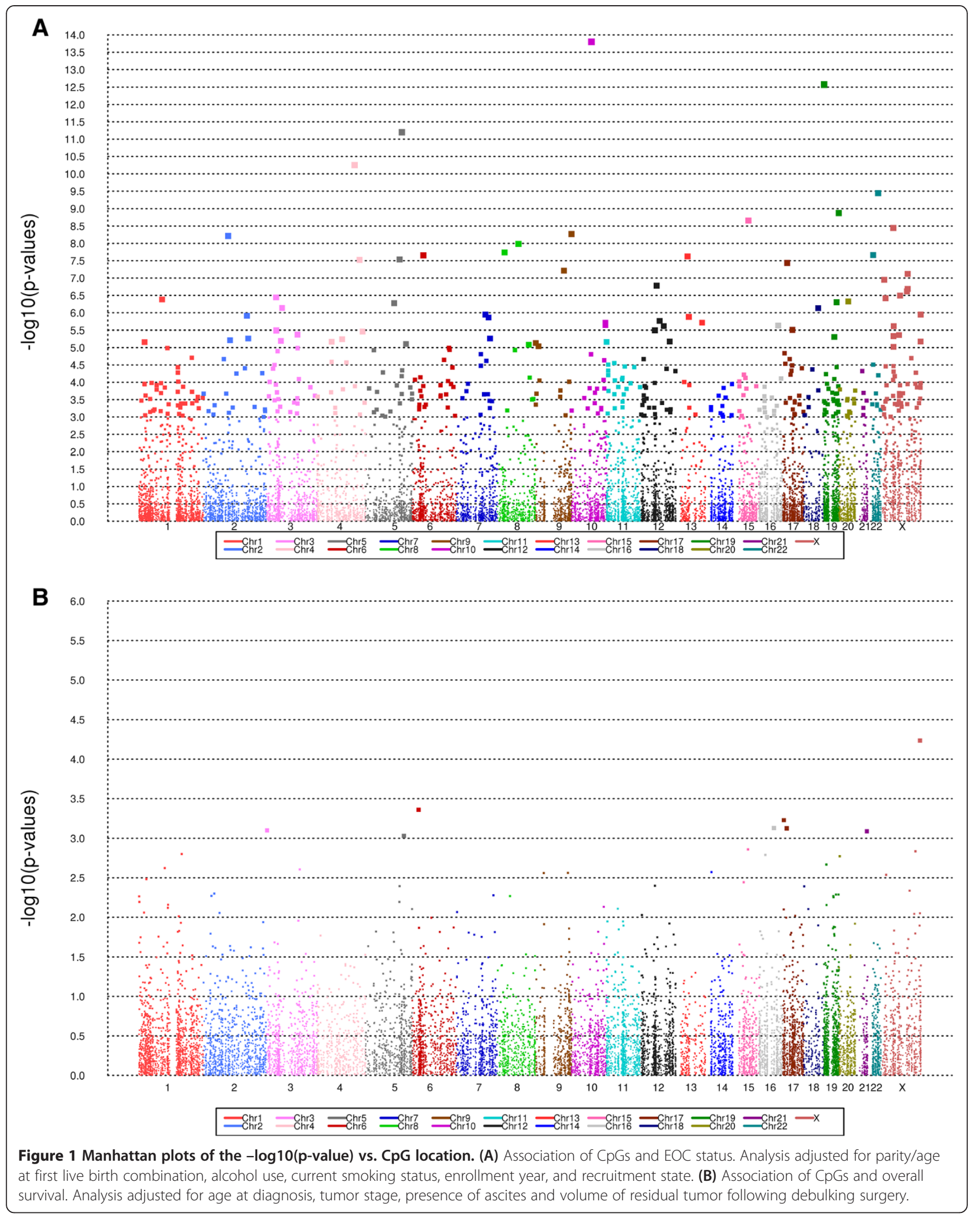



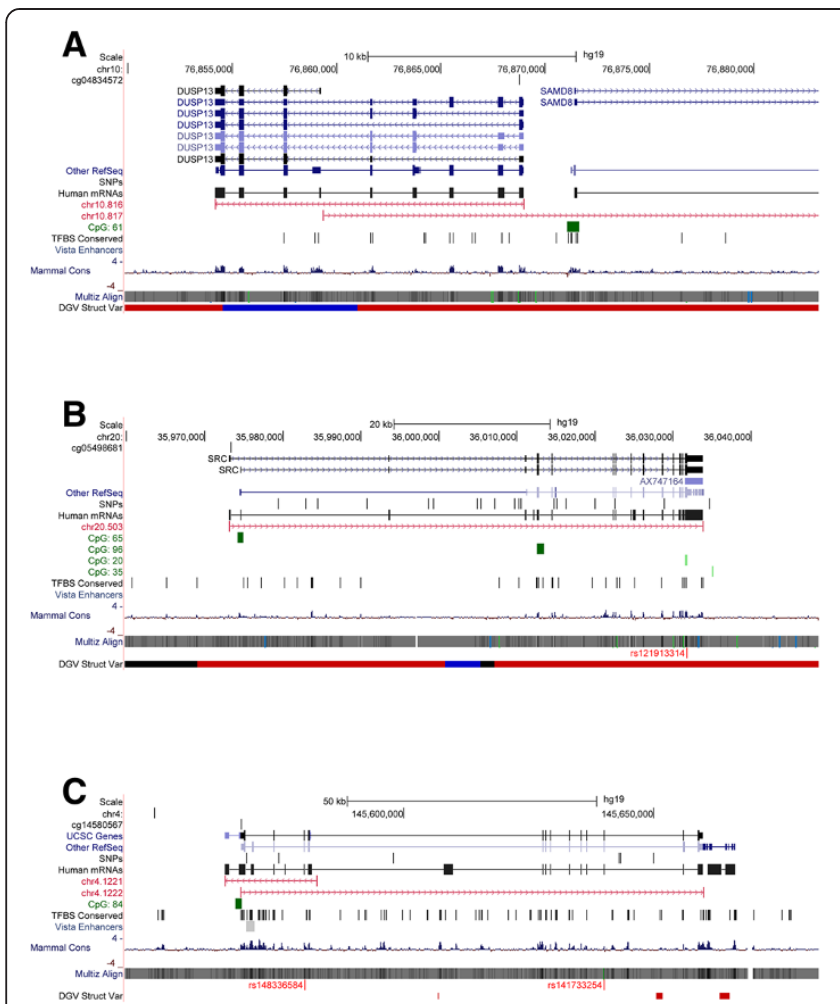

Figure 2 Differential methylation regions between EOC cases and controls displayed in UCSC Genome Browser. (A) DUSP13 region; (B) SRC region; (C) HHIP region; (D) HDAC3 region; and (E) CUL7 region.

$\left.4.33 \times 10^{-6}\right), \quad$ PIK $3 C 2 B \quad\left(\mathrm{p}=1.97 \times 10^{-5}\right), \quad$ PIK $3 R 1 \quad(\mathrm{p}=$ $\left.5.19 \times 10^{-5}\right)$, and POT1 $\left(\mathrm{p}=1.38 \times 10^{-6}\right)$. PIK $3 C 2 B$ has been implicated in development of glioblastoma multiforme, while mutations in PIK3R1 have been seen in ovarian tumors and cancer cell lines and endometrial cancer [21-23]. POT1 has been found to be associated with tumor stage and telomere length in gastric cancer [24-26]. For the paxillin signaling pathway, the five differentially methylated CpGs were near ARFIP2 $\left(\mathrm{p}=4.60 \times 10^{-5}\right)$, ITGB6 $(\mathrm{p}=$ $\left.3.95 \times 10^{-5}\right), P I K 3 C 2 B, P I K 3 R 1$ and $S R C$, with some overlap between the top two pathways (PIK3R1 and PIK3C2B).

\section{Survival following EOC and DNA methylation}

Many fewer CpGs were associated with OS among the 366 cases than with case-control status, as illustrated in Figure $1 \mathrm{~B}$. None of the associations were statistically significant at the $5 \times 10^{-6}$ level; the top eight CpG probes with meta-analysis $\mathrm{p}$-value $<10^{-3}$ for association with OS are presented in Table 2. The top CpG sites associated with OS were cg10276549 within the promoter region of GABRE $\left(\mathrm{p}=5.8 \times 10^{-5}\right)$ (Figure $3 \mathrm{~A}$ ) and $\mathrm{CpG}$ site (cg06171242) within the promoter region of TTRAP/ TDP2 $\left(\mathrm{p}=4.4 \times 10^{-4}\right)$. GABRE is a target for many benzodiazepine drugs used in the treatment of pain, insomnia, epilepsy, anxiety and panic related disorders [27-29]. However, little information can be found implicating a
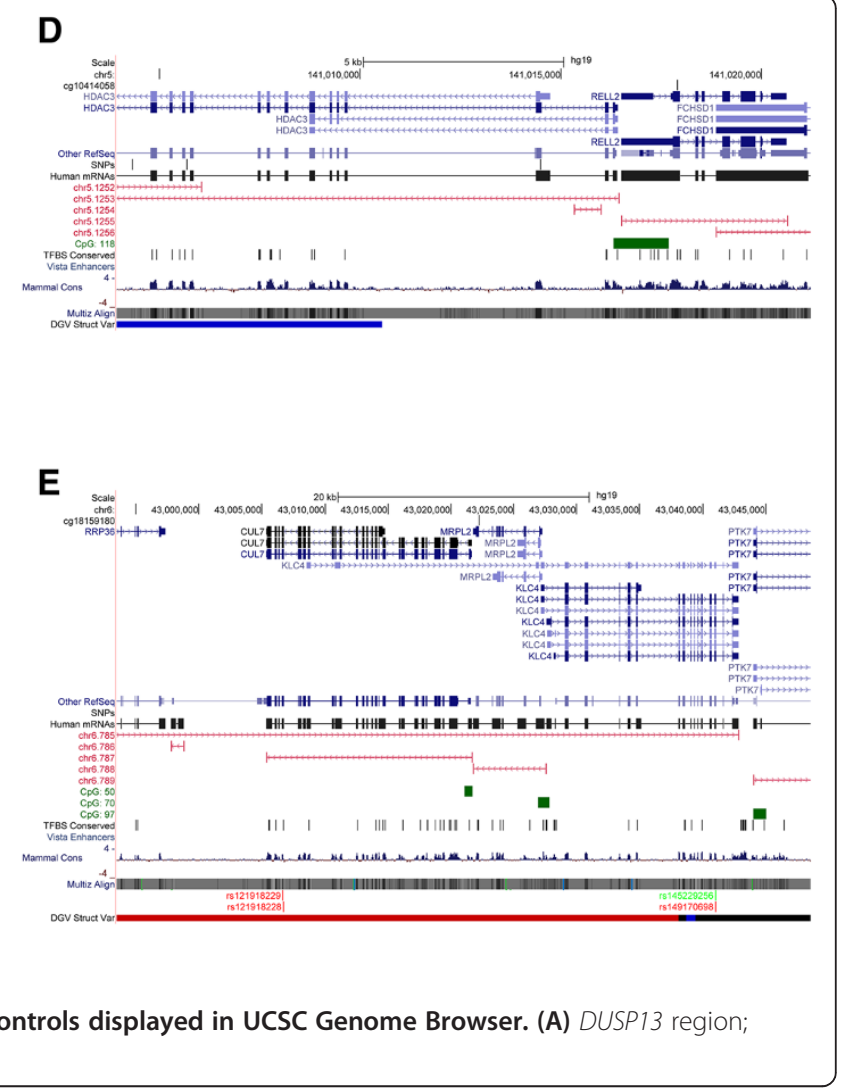

role of GABRE in response to chemotherapies (http:// www.cancer.gov/clinicaltrials/). In addition to the modest level of association for CpGs near GABRE, there was a trend for association of $\mathrm{CPG}$ sites near the following biologically relevant genes: $M T 1 X\left(\mathrm{p}=7.4 \times 10^{-4}\right)$ (Figure $\left.3 \mathrm{~B}\right)$, $A D O R A 2 B\left(\mathrm{p}=7.4 \times 10^{-4}\right)$ (Figure $\left.3 \mathrm{C}\right)$, and $A B L M 3(\mathrm{p}=$ $\left.9.3 \times 10^{-4}\right)$. These three $\mathrm{CpG}$ sites moderately associated with OS were all within $\mathrm{CpG}$ islands or shores and within the promoter region of the corresponding gene.

Similar to the analysis of the disease-associated genes, an exploratory pathway analysis using IPA was completed for the 61 genes closest to the $\mathrm{CpG}$ probes most associated with OS (meta-analysis $\mathrm{p}<0.01$ ). The top canonical pathways enriched for these 61 genes were relaxin signaling (five genes out of 147; GNA12, GNB1, PIK3R4, RAP1A, TDP2; $\mathrm{p}=7.09 \times 10^{-5}$ for enrichment of pathway) and CXCR4 signaling (five genes out of 160; GNA12, GNB1, ITPR1, PIK3R4, ROCK1; $\mathrm{p}=1.25 \times 10^{-4}$ ) and IL-8 signaling (five genes out of 192; ARRB2, GNA12, GNB1, PIK3R4, ROCK1; $\left.\mathrm{p}=3.05 \times 10^{-4}\right)$. Three genes $(G N B 1(\mathrm{p}=0.006)$, GNA12 $(\mathrm{p}=0.009)$, and PIK3R4 $(\mathrm{p}=0.002))$ are part of all three of these canonical pathways.

\section{Discussion}

Via a CpG-by-CpG approach excluding CpGs known to correlate with potentially confounding white blood cell 


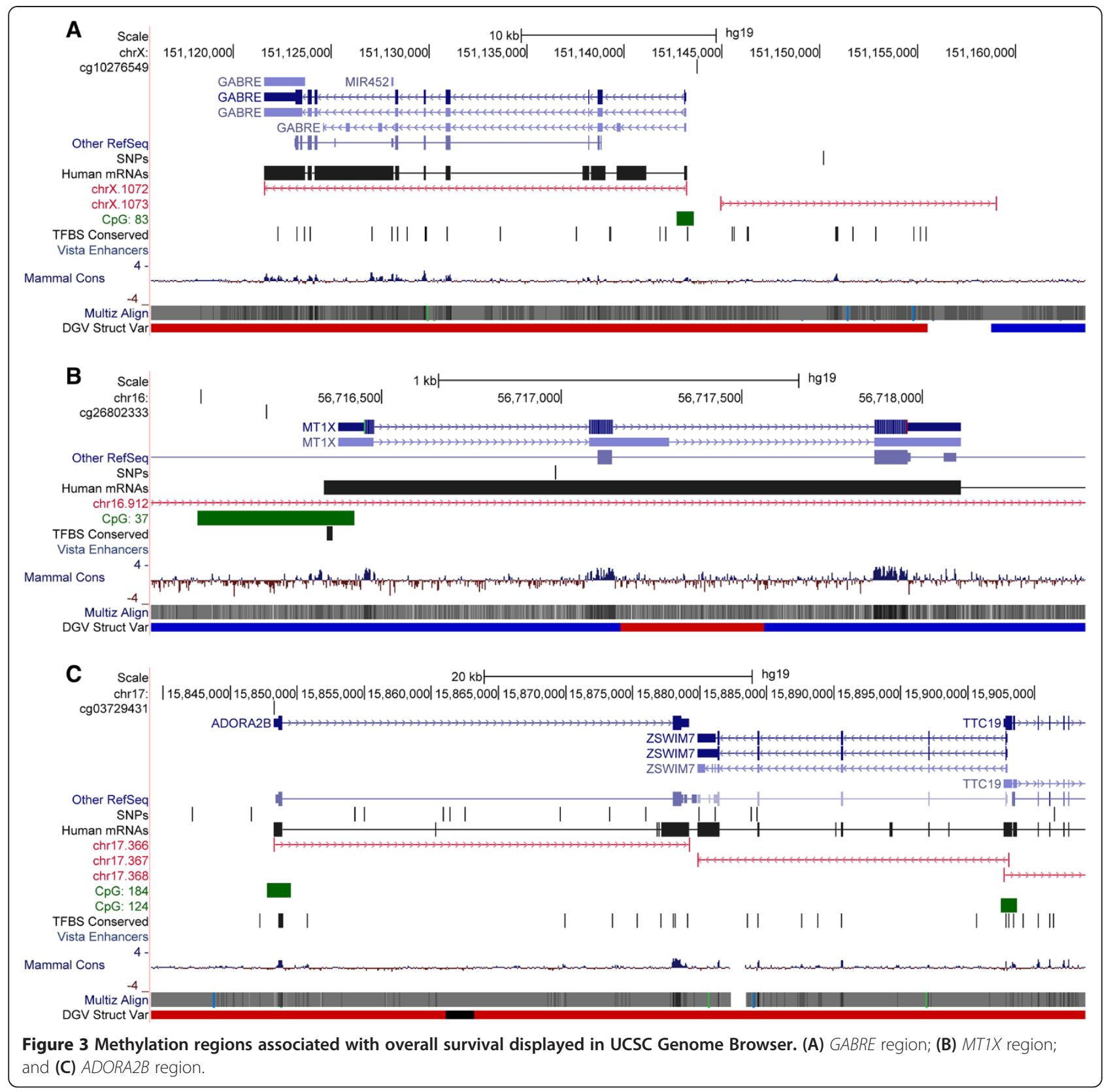

types, we identified methylation CpG sites (and corresponding neighboring genes) with differential specific hyper- or hypo-methylation signals by case-control status and by survival time. To increase power to detect differentially methylated $\mathrm{CpG}$ sites, we completed a metaanalysis of results from three DNAm experiments using two genome-wide methylation arrays, restricting focus to high quality probes on both arrays.

A number of $\mathrm{CpG}$ sites were found to be differentially methylated between EOC cases and age-matched controls (Table 2). The CpG site that was most differentially methylated between EOC cases and controls was cg04834572 located at the splice region of exon 1 and intron 1 of
DUSP13 $\left(\mathrm{p}=1.6 \times 10^{-14}\right)$. The blood-based methylation of this $\mathrm{CpG}$ site was also reported to be associated with EOC risk in a previous study with $\mathrm{p}=0.002$ (Figure 2A) [14]. In addition to the replication of the association for the methylation site at DUSP13, four regions identified in this study were replicated for association EOC risk with a $\mathrm{p} \leq$ 0.001, as reported in Teschendorff et al. [14]: cg02449608 (C19orf18, $\mathrm{p}=0.0002), \quad$ cg19280776 (PAG1, $\mathrm{p}=8 \times 10^{-6}$ ); cg17271365 (MARCH1, p = 2×10-5), cg10414058 (HDAC3, $\mathrm{p}=0.001)$, and $\operatorname{cg} 24959428(G B P 6, \mathrm{p}=0.001)$.

Many of the genes neighboring the top associated CpG sites have biological relevance to cancer development. Methylation at a CpG site on chromosome 20 at bp 
35973318 (cg0549868), located within the splicing region of exon 1 and intron 1 of gene SRC (35973088$36033821 \mathrm{bp})$, was found to be associated with EOC risk $\left(\mathrm{p}=4.8 \times 10^{-7}\right)$ (Figure $\left.2 \mathrm{~B}\right) . S R C$ is a proto-oncogene which regulates EGFR, Akt, MAPK1 and NF-kB. SRC is a target for many anticancer drugs [30]. A CpG island (cg14580567, bp 145567271) within HHIP (145567148-145659881 bp) was also found to be associated with EOC risk ( $\mathrm{p}=$ $\left.5.6 \times 10^{-11}\right)$. The genomic region surrounding HHIP (hedgehog-interacting protein) (Figure 2C) has been implicated in many cancers, with hypermethylation of the promoter region found to down-regulate the expression of HHIP found in many tumors, such as gastric and pancreatic cancer [31]. The hedgehog proteins are evolutionarily conserved and are important for a wide range of developmental processes; members of this family control cell proliferation and differentiation, thus linking them with many cancers, including basal-cell carcinoma, small cell lung cancer and pancreatic cancer [32].

The methylation at a $\mathrm{CpG}$ site in the shore of a $\mathrm{CpG}$ island, approximately $2.5 \mathrm{~kb}$ upstream of $H D A C 3$, was observed to be associated with EOC risk $\left(\mathrm{p}=6.3 \times 10^{-13}\right)$ (Figure 2D). This association was also observed in a previous study $(p=0.001)$ [14]. Other studies looking at the role of histone deacetylases (HDACs) found that the expression of $\mathrm{HDAC} 1$, along with the expression levels of HDAC2 and HDAC3, to be increased in ovarian tumors compared to levels in benign tumors and normal tissue, suggesting the oncogenic potential of HDACs in ovarian tumors [33-35]. Lastly, a CpG site near CUL7 (cg18159180, $\mathrm{p}=2.2 \times 10^{-8}$ ) was differentially methylated between EOC cases and controls; CUL7 has been shown to block Myc-induced apoptosis in a p53-dependent manner (Figure 2E) [36,37].
In addition to individual CpG sites associated with EOC risk, we also found the telomerase signaling and paxillin signaling pathways to be enriched for genes with CpGs that were differentially methylated between cases and controls. The telomerase signaling pathway and inherited variation in TERT have been found to be associated with the development of EOC and other cancers [11]. The maintenance of functional telomeres is critical in that telomeres that become too short are unable to protect the chromosome from DNA damage. TERT plays an extensive role in the maintenance of functional telomeres, and TERT can be activated by AKT and HSP90 and inhibited by c-Abl. One gene identified to be moderately associated with EOC risk was PIK3R1, which is also a member of the telomerase signaling pathway. PIK3R1 is involved in ATPase and estrogen receptor binding and regulates numerous genes, such as $A K T, N F K B, T N F$, and is involved in apoptosis, proliferation and differentiation. PIK3R1 has also been linked to epithelial neoplasia and cancer, endometrial ovarian cancer, and endometrioid carcinoma [20,22,23,38]. In contrast, the paxillin signaling pathway is involved in the recruitment of signaling and structural proteins to paxillin required for regulation of cell motility, with many of the paxillin-binding proteins having oncogenic equivalents.

In contrast to the findings for EOC risk, we found no statistically significant CpG probes associated with OS following EOC (Table 3). However, many of genes surrounding these $\mathrm{CpG}$ sites have potential biological relevance and would be warranted for future follow-up. In particular, the gene GABRE (Figure 3A) is a target for many benzodiazepine agents [27,28]; MT1X (Figure 3B) has been implicated in resistance to cisplatin therapy in oral squamous cell carcinoma and irinotecan resistance in gastric cancer patients $[39,40] ; A D O R A 2 B$ (Figure $3 C$ )

Table 3 CpG sites associated with overall survival following EOC $\left(p<10^{-3}\right)$

\begin{tabular}{|c|c|c|c|c|c|c|c|c|c|c|c|c|c|}
\hline \multirow{2}{*}{ Probe } & \multirow{2}{*}{$\mathrm{Ch}$} & \multirow{2}{*}{$\begin{array}{l}\text { Position } \\
\text { (bp) }\end{array}$} & \multirow{2}{*}{$\begin{array}{l}\text { Nearest } \\
\text { genes }\end{array}$} & \multirow{2}{*}{$\begin{array}{l}\text { Location of nearest } \\
\text { gene (bp) }\end{array}$} & \multirow{2}{*}{$\begin{array}{l}\text { Relation } \\
\text { to Island^ }\end{array}$} & \multicolumn{2}{|c|}{ Meta-Analysis* } & \multicolumn{2}{|c|}{ Batch 1} & \multicolumn{2}{|c|}{ Batch 2} & \multicolumn{2}{|c|}{ Batch 3} \\
\hline & & & & & & HR & $\mathbf{P}$ & HR & $\mathbf{P}$ & HR & $\mathbf{P}$ & HR & $\mathbf{P}$ \\
\hline $\operatorname{cg} 10276549$ & $x$ & 151143686 & GABRE & $151121596-151143151$ & Shore & 0.95 & $5.8 \mathrm{E}-5$ & 0.96 & 0.32 & 0.97 & 0.19 & 0.94 & $2.9 \mathrm{E}-4$ \\
\hline $\operatorname{cg} 06171242$ & 6 & 24667490 & $\begin{array}{c}\text { ACOT13 } \\
\text { TTRAP/TDP2 }\end{array}$ & $\begin{array}{l}24667263-24705297 \\
24650205-24667115\end{array}$ & Shore & 1.10 & $4.4 \mathrm{E}-4$ & 1.20 & 0.22 & 1.11 & $7.2 \mathrm{E}-3$ & 1.02 & 0.87 \\
\hline cg14360897 & 17 & 4843676 & $\begin{array}{l}\text { RNF167 } \\
\text { SLC25A11 }\end{array}$ & $\begin{array}{l}4843630-4848517 \\
4840425-4843462\end{array}$ & Shore & 1.22 & $5.9 \mathrm{E}-4$ & 1.25 & 0.084 & 1.29 & $3.8 \mathrm{E}-3$ & 1.13 & 0.20 \\
\hline $\operatorname{cg} 26802333$ & 16 & 56716182 & MT1X & $56716382-56718108$ & Island & 1.07 & $7.4 \mathrm{E}-4$ & 1.11 & 0.044 & 1.07 & $1.2 \mathrm{E}-3$ & 1.00 & 0.97 \\
\hline cg03729431 & 17 & 15848264 & $A D O R A 2 B$ & $15848231-15879210$ & Island & 1.11 & $7.5 \mathrm{E}-4$ & 0.97 & 0.85 & 1.12 & $5.8 \mathrm{E}-3$ & 1.09 & 0.69 \\
\hline cg21858376 & 3 & 4534791 & ITPR1 & $4535032-4889524$ & Island & 1.12 & $7.9 \mathrm{E}-4$ & 1.31 & 0.11 & 1.11 & 0.022 & 1.09 & 0.37 \\
\hline cg12003230 & 21 & 44899139 & $\begin{array}{l}\text { C21orf84/ } \\
\text { LINC00313 }\end{array}$ & $44881974-44898103$ & & 0.86 & $8.1 \mathrm{E}-4$ & 0.82 & 0.022 & 0.85 & $8.9 \mathrm{E}-3$ & 0.97 & 0.72 \\
\hline cg05026186 & 5 & 148520876 & $A B L I M 3$ & $148521054-148639999$ & Shore & 0.96 & $9.3 \mathrm{E}-4$ & 0.98 & 0.41 & 0.96 & $5.3 E-3$ & 0.96 & 0.071 \\
\hline
\end{tabular}

\#Locations based on NCBI (www.ncbi.nlm.nih.gov), build 37.

$\wedge$ Shore CpG sites defined to be within $+/-2$ kb from CpG island; Shelf CpG sites defined to be within $+/-2 \mathrm{~kb}$ of CpG Shore.

*All tests for heterogeneity of effects across the three batches were non-significant ( $>0.05$ ); analysis adjusted for age at diagnosis, tumor stage, presence of ascites and volume of residual tumor following debulking surgery. 
is an antagonist in many drugs (such as dyphylline and aminophylline, used in treatment of asthma and pulmonary emphysema), with recent research discovering antagonists of $A D O R A 2 B$ are preferentially toxic to breast tumor cells expressing Fra-1, a candidate metastasis gene and expression of $A D O R A 2 B$ up-regulated in colorectal carcinoma tissues and cell lines [41,42].

Single CpG probe analysis of the association of bloodbased DNAm with survival following EOC, followed by pathway analyses found the top pathways to all contain three genes (GNB1, GNA12, and PIK3R4), although individual $C p G$ evidence for these three genes were modest. The standard chemotherapy regimen for EOC patients following surgery is a combination therapy involving a taxane (e.g., paclitaxel) and platinum (e.g., cisplatin, carboplatin) agent, increasing our interest in the gene GNA12 found to be associated with response to cisplatin/paclitaxel [43]. Guanine nucleotide binding protein (G protein), beta polypeptide 1 (GNB1) has been recently found to be associated with breast cancer outcomes and clinical and pathological measurements [44]. PIK3R4 is a member of the phosphoinositide 3-kinases (PI3Ks) family that is involved in multiple cell functions (e.g., proliferation, cell survival, degranulation), and this gene is a novel candidate for outcome following EOC.

In summary, we have identified several methylation CpGs sites, using blood-based or leukocyte DNAm, which are differentially methylated by case-control status. Of these CpGs, four CpGs and two genes containing significant CpGs were replicated in an independent study of DNAm and EOC risk. Strengths of our study are large sample size, exclusion of CpGs associated with white blood cell types, and inclusion of relevant covariates. Prior work in a smaller set of cases and controls showed that blood-based DNAm associated with case-control status [14], thus providing additional evidence to "confirmed" $\mathrm{CpG}$ regions associated with EOC. To ensure that none of our findings could be attributed to confounding due to cell type distribution, we removed of probes associating with cell types (which in fact showed very strong associations with case-control status; data not shown). In addition to these strengths, there are also limitations to this study. First, this study was limited to CpG sites assayed on the Illumina array; future application of genome-wide DNA methylation sequencing (i.e., methyl-seq) will enable additional EOC related methylation marks to be discovered. Secondly, the retrospective case-control design used in this study precludes interpretation of these results as indicators of EOC risk. As blood was drawn upon diagnosis, we cannot exclude the possibility that the case-control differences resulted from the cancer itself, from its treatment, or from lifestyle changes. Nonetheless, this short list of CpGs should be of high priority for cohort studies with baseline blood draws and follow-up for later EOC. We note that our survival studies were limited primarily by sample size (336 cases), and thus may have been underpowered to detect modest effects; combining this study with other blood-based methylation case studies will be a key next step.

\section{Conclusion}

In conclusion, this early examination of blood-based DNAm provides added experience to a relatively nascent field, suggesting that careful pre-processing and consideration of probes associating with distributions of white blood cell types is critical. We also report specific CpGs that associate either with case-control status or outcome, which are worthy of follow-up in prospective cohort and clinical studies.

\section{Additional file}

Additional file 1: Figure S1. Plot of the $1^{\text {st }}$ and $2^{\text {nd }}$ principal

components for each of the three batches before and after the

normalization step. The different colors in the figures represent the

different plates of 96 samples in each batch. Batch 1 Pre (A) and Post (B)

adjustment; Batch 2 Pre (C) and Post (D) adjustment; Batch 3 Pre (E) and

Post (F) adjustment.

Competing interest

The authors declare that they have no conflict of interest.

\section{Authors' contributions}

ELG, JMC, BLF, JEO, KRK, and MSC participated in the design of the study and coordination. MSC, KRK, VS, JMC prepared the samples and completed the assays for measuring DNA methylation. BLF, SMA, MCL carried out the statistical analyses included the manuscript. DNR provided the annotation of the regions and CpGs. CW, SW and DCK were involved in the quality control and normalization of the DNA methylation array data, in addition to BLF, SMA and MCL. BLF and ELG drafted the manuscript. All authors read and approved the final manuscript.

\section{Acknowledgements}

Funding was provided by the Fred C. and Katherine B. Andersen Foundation and the US National Institute of Health (P30 CA168524, P50 CA136393, R01 CA122443, P20 GM103418, R21 GM86689).

\section{Author details}

'Department of Biostatistics, University of Kansas, Medical Center, 3901 Rainbow Blvd, Kansas City, KS 66160, USA. '2Department of Health Sciences Research, Mayo Clinic College of Medicine, Rochester, MN 55905, USA. ${ }^{3}$ Department of Medicine, Mayo Clinic College of Medicine, Rochester, MN 55905, USA. ${ }^{4}$ Department of Community and Family Medicine, Geisel School of Medicine at Dartmouth College, Lebanon, NH 03756, USA. ${ }^{5}$ Department of Laboratory Medicine and Pathology, Mayo Clinic College of Medicine, Rochester, MN 55905, USA.

Received: 13 December 2013 Accepted: 16 April 2014 Published: 28 April 2014

\section{References}

1. Cancer Genome Atlas Research Network: Integrated genomic analyses of ovarian carcinoma. Nature 2011, 474(7353):609-615.

2. Cicek MS, Koestler DC, Fridley BL, Kalli KR, Armasu SM, Larson MC, Wang C, Winham SJ, Vierkant RA, Rider DN, Block MS, Klotzle B, Konecny G, Winterhoff BJ, Hamidi H, Shridhar V, Fan JB, Visscher DW, Olson JE, Hartmann LC, Bibikova M, Chien J, Cunningham JM, Goode EL: Epigenomewide ovarian cancer analysis identifies a methylation profile 
differentiating clear-cell histology with epigenetic silencing of the HERG K+ channel. Hum Mol Genet 2013, 22(15):3038-3047.

3. Rakyan VK, Down TA, Balding DJ, Beck S: Epigenome-wide association studies for common human diseases. Nat Rev Genet 2011, 12(8):529-541.

4. Tsai PC, Spector TD, Bell JT: Using epigenome-wide association scans of DNA methylation in age-related complex human traits. Epigenomics 2012, 4(5):511-526.

5. Brennan K, Flanagan JM: Epigenetic epidemiology for cancer risk: harnessing germline epigenetic variation. Methods Mol Biol 2012, 863:439-465.

6. Brennan K, Flanagan JM: Is there a link between genome-wide hypomethylation in blood and cancer risk? Cancer Prev Res (Phila) 2012, 5(12):1345-1357.

7. Shenker NS, Polidoro S, van Veldhoven K, Sacerdote C, Ricceri F, Birrell MA, Belvisi MG, Brown R, Vineis P, Flanagan JM: Epigenome-wide association study in the European Prospective Investigation into Cancer and Nutrition (EPIC-Turin) identifies novel genetic loci associated with smoking. Hum Mol Genet 2013, 22(5):843-851.

8. Pedersen KS, Bamlet WR, Oberg AL, de Andrade M, Matsumoto ME, Tang H, Thibodeau SN, Petersen GM, Wang L: Leukocyte DNA methylation signature differentiates pancreatic cancer patients from healthy controls. PLoS One 2011, 6(3)::18223.

9. Goode EL, Chenevix-Trench G, Song H, Ramus SJ, Notaridou M, Lawrenson K, Widschwendter M, Vierkant RA, Larson MC, Kjaer SK, Birrer MJ, Berchuck A, Schildkraut J, Tomlinson I, Kiemeney LA, Cook LS, Gronwald J, Garcia-Closas M, Gore ME, Campbell I, Whittemore AS, Sutphen R, Phelan C, Anton-Culver H, Pearce CL, Lambrechts D, Rossing MA, Chang-Claude J, Moysich KB, Goodman MT, et al: A genome-wide association study identifies susceptibility loci for ovarian cancer at 2q31 and 8q24. Nat Genet 2010, 42(10):874-879.

10. Song H, Ramus SJ, Tyrer J, Bolton KL, Gentry-Maharaj A, Wozniak E, Anton-Culver H, Chang-Claude J, Cramer DW, DiCioccio R, Dork T, Goode EL, Goodman MT, Schildkraut JM, Sellers T, Baglietto L, Beckmann MW, Beesley J, Blaakaer J, Carney ME, Chanock S, Chen Z, Cunningham JM, Dicks E, Doherty JA, Durst M, Ekici AB, Fenstermacher D, Fridley BL, Giles G, et al: A genome-wide association study identifies a new ovarian cancer susceptibility locus on 9p22.2. Nat Genet 2009, 41(9):996-1000.

11. Bojesen SE, Pooley KA, Johnatty SE, Beesley J, Michailidou K, Tyrer JP, Edwards SL, Pickett HA, Shen HC, Smart CE, Hillman KM, Mai PL, Lawrenson K, Stutz MD, Lu Y, Karevan R, Woods N, Johnston RL, French JD, Chen X, Weischer M, Nielsen SF, Maranian MJ, Ghoussaini M, Ahmed S, Baynes C, Bolla MK, Wang Q, Dennis J, McGuffog L, et al: Multiple independent variants at the TERT locus are associated with telomere length and risks of breast and ovarian cancer. Nat Genet 2013, 45(4):371-384. 384e371-372.

12. Shen H, Fridley BL, Song H, Lawrenson K, Cunningham JM, Ramus SJ, Cicek MS, Tyrer J, Stram D, Larson MC, Kobel M, Consortium P, Ziogas A, Zheng W, Yang HP, Wu AH, Wozniak EL, Woo YL, Winterhoff B, Wik E, Whittemore AS, Wentzensen N, Weber RP, Vitonis AF, Vincent D, Vierkant RA, Vergote I, Van Den Berg D, Van Altena AM, Tworoger SS, et al: Epigenetic analysis leads to identification of HNF1B as a subtype-specific susceptibility gene for ovarian cancer. Nat Commun 2013, 4:1628.

13. Painter JN, Anderson CA, Nyholt DR, Macgregor S, Lin J, Lee SH, Lambert A, Zhao ZZ, Roseman F, Guo Q, Gordon SD, Wallace L, Henders AK, Visscher PM, Kraft P, Martin NG, Morris AP, Treloar SA, Kennedy SH, Missmer SA, Montgomery GW, Zondervan KT: Genome-wide association study identifies a locus at 7p15.2 associated with endometriosis. Nat Genet 2011, 43(1):51-54.

14. Teschendorff AE, Menon U, Gentry-Maharaj A, Ramus SJ, Gayther SA, Apostolidou S, Jones A, Lechner M, Beck S, Jacobs IJ, Widschwendter M: An epigenetic signature in peripheral blood predicts active ovarian cancer. PLoS One 2009, 4(12):e8274.

15. Koestler DC, Marsit CJ, Christensen BC, Accomando W, Langevin SM Houseman EA, Nelson HH, Karagas MR, Wiencke JK, Kelsey KT: Peripheral blood immune cell methylation profiles are associated with nonhematopoietic cancers. Cancer Epidemiol Biomarkers Prev 2012, 21(8):1293-1302.

16. Houseman EA, Accomando WP, Koestler DC, Christensen BC, Marsit C Nelson $\mathrm{HH}$, Wiencke JK, Kelsey KT: DNA methylation arrays as surrogate measures of cell mixture distribution. BMC Bioinformatics 2012, 13(1):86.

17. Chen YA, Choufani S, Ferreira JC, Grafodatskaya D, Butcher DT, Weksberg R: Sequence overlap between autosomal and sex-linked probes on the Illumina HumanMethylation27 microarray. Genomics 2011, 97(4):214-222.

18. Grambsch PM, Therneau TM: Proportional hazards tests and diagnostics based on weighted residuals. Biometrika 1994, 81(3):515-526.

19. Therneau TM, Grambsch PM, Fleming TR: Martingale-based residuals for survival models. Biometrika 1990, 77:147-160.
20. Sjodahl G, Lauss M, Gudjonsson S, Liedberg F, Hallden C, Chebil G, Mansson W, Hoglund M, Lindgren D: A systematic study of gene mutations in urothelial carcinoma; inactivating mutations in TSC2 and PIK3R1. PLoS One 2011, 6(4):e18583.

21. Rao SK, Edwards J, Joshi AD, Siu IM, Riggins GJ: A survey of glioblastoma genomic amplifications and deletions. J Neurooncol 2010, 96(2):169-179.

22. Philp AJ, Campbell IG, Leet C, Vincan E, Rockman SP, Whitehead RH, Thomas RJ, Phillips WA: The phosphatidylinositol 3'-kinase p85alpha gene is an oncogene in human ovarian and colon tumors. Cancer Res 2001, 61(20):7426-7429.

23. Urick ME, Rudd ML, Godwin AK, Sgroi D, Merino M, Bell DW: PIK3R1 (p85alpha) is somatically mutated at high frequency in primary endometrial cancer. Cancer Res 2011, 71(12):4061-4067.

24. Kondo T, Oue N, Yoshida K, Mitani Y, Naka K, Nakayama H, Yasui W: Expression of POT1 is associated with tumor stage and telomere length in gastric carcinoma. Cancer Res 2004, 64(2):523-529.

25. Ning X, Yang S, Wang R, Zhang R, Guo L, Tie J, Cheng Y, Wang G, Wan S, Fang D: POT1 deficiency alters telomere length and telomere-associated gene expression in human gastric cancer cells. Eur J Cancer Prev 2010, 19(5):345-351.

26. Wan $S M$, Tie J, Zhang YF, Guo J, Yang LQ, Wang J, Xia SH, Yang SM, Wang RQ, Fang DC: Silencing of the hPOT1 gene by RNA inference promotes apoptosis and inhibits proliferation and aggressive phenotype of gastric cancer cells, likely through up-regulating PinX1 expression. J Clin Pathol 2011, 64(12):1051-1057.

27. Mohler H, Fritschy JM, Rudolph U: A new benzodiazepine pharmacology. J Pharmacol Exp Ther 2002, 300(1):2-8.

28. Riss J, Cloyd J, Gates J, Collins S: Benzodiazepines in epilepsy: pharmacology and pharmacokinetics. Acta Neurol Scand 2008, 118(2):69-86.

29. Salzman C, Miyawaki EK, le Bars P, Kerrihard TN: Neurobiologic basis of anxiety and its treatment. Harv Rev Psychiatry 1993, 1(4):197-206.

30. Yeatman TJ: A renaissance for SRC. Nat Rev Cancer 2004, 4(6):470-480.

31. Katoh $Y$, Katoh M: Hedgehog signaling pathway and gastric cancer. Cancer Biol Ther 2005, 4(10):1050-1054.

32. Pasca di Magliano M, Hebrok M: Hedgehog signalling in cancer formation and maintenance. Nat Rev Cancer 2003, 3(12):903-911.

33. Hayashi A, Horiuchi A, Kikuchi N, Hayashi T, Fuseya C, Suzuki A, Konishi I, Shiozawa T: Type-specific roles of histone deacetylase (HDAC) overexpression in ovarian carcinoma: HDAC1 enhances cell proliferation and HDAC3 stimulates cell migration with downregulation of E-cadherin. Int J Cancer 2010, 127(6):1332-1346.

34. Khabele D, Son DS, Parl AK, Goldberg GL, Augenlicht LH, Mariadason JM, Rice VM: Drug-induced inactivation or gene silencing of class I histone deacetylases suppresses ovarian cancer cell growth: implications for therapy. Cancer Biol Ther 2007, 6(5):795-801.

35. Jin KL, Pak JH, Park JY, Choi WH, Lee JY, Kim JH, Nam JH: Expression profile of histone deacetylases 1, 2 and 3 in ovarian cancer tissues. J Gynecol Oncol 2008, 19(3):185-190.

36. Jung P, Verdoodt B, Bailey A, Yates JR 3rd, Menssen A, Hermeking H: Induction of cullin 7 by DNA damage attenuates p53 function. Proc Natl Acad Sci U S A 2007, 104(27):11388-11393.

37. Kim SS, Shago M, Kaustov L, Boutros PC, Clendening JW, Sheng Y, Trentin GA, Barsyte-Lovejoy D, Mao DY, Kay R, Jurisica I, Arrowsmith CH, Penn LZ: CUL7 is a novel antiapoptotic oncogene. Cancer Res 2007, 67(20):9616-9622.

38. Jaiswal BS, Janakiraman V, Kljavin NM, Chaudhuri S, Stern HM, Wang W, Kan Z Dbouk HA, Peters BA, Waring P, Dela Vega T, Kenski DM, Bowman KK, Lorenzo M, Li H, Wu J, Modrusan Z, Stinson J, Eby M, Yue P, Kaminker JS, de Sauvage FJ, Backer JM, Seshagiri S: Somatic mutations in p85alpha promote tumorigenesis through class IA PI3K activation. Cancer Cell 2009, 16(6):463-474.

39. Peng B, Gu Y, Xiong Y, Zheng G, He Z: Microarray-assisted pathway analysis identifies MT1X \& NFkappaB as mediators of TCRP1-associated resistance to cisplatin in oral squamous cell carcinoma. PLoS One 2012, 7(12): 551413.

40. Chun JH, Kim HK, Kim E, Kim IH, Kim JH, Chang HJ, Choi IJ, Lim HS, Kim IJ, Kang HC, Park JH, Bae JM, Park JG: Increased expression of metallothionein is associated with irinotecan resistance in gastric cancer. Cancer Res 2004, 64(14):4703-4706.

41. Desmet CJ, Gallenne T, Prieur A, Reyal F, Visser NL, Wittner BS, Smit MA, Geiger TR, Laoukili J, Iskit S, Rodenko B, Zwart W, Evers B, Horlings H, Ajouaou A, Zevenhoven J, van Vliet M, Ramaswamy S, Wessels LF, Peeper DS: Identification of a pharmacologically tractable Fra-1/ADORA2B axis 
promoting breast cancer metastasis. Proc Natl Acad Sci U S A 2013, 110(13):5139-5144.

42. Ma DF, Kondo T, Nakazawa T, Niu DF, Mochizuki K, Kawasaki T, Yamane T, Katoh R: Hypoxia-inducible adenosine A2B receptor modulates proliferation of colon carcinoma cells. Hum Pathol 2010, 41(11):1550-1557.

43. Barreto B, Feher O, Carvalho A, Cristo E, Neves E, Kowalski L, Reis L: Molecular classifiers as predictors of responsiveness to concomitant chemoradiotherapy in SCC of the larynx. AACR Meeting Abstracts 2008 2008, 2008(1_Annual_Meeting):4142.

44. Wazir U, Jiang WG, Sharma AK, Mokbel K: Guanine nucleotide binding protein beta 1: a novel transduction protein with a possible role in human breast cancer. Cancer Genomics Proteomics 2013, 10(2):69-73.

doi:10.1186/1755-8794-7-21

Cite this article as: Fridley et al:: Methylation of leukocyte DNA and ovarian cancer: relationships with disease status and outcome. BMC Medical Genomics 2014 7:21.

\section{Submit your next manuscript to BioMed Central and take full advantage of:}

- Convenient online submission

- Thorough peer review

- No space constraints or color figure charges

- Immediate publication on acceptance

- Inclusion in PubMed, CAS, Scopus and Google Scholar

- Research which is freely available for redistribution 